\title{
Lipopeptide antibiotic production by Bacillus velezensis KLP2016
}

\author{
Khem Raj Meena, Tanuja Tandon, Abhishek Sharma, Shamsher S. Kanwar* \\ Department of Biotechnology, Himachal Pradesh University, Shimla-171 005, India.
}

\begin{tabular}{|c|c|}
\hline ARTICLE INFO & ABSTRACT \\
\hline $\begin{array}{l}\text { Article history: } \\
\text { Received on: } 20 / 11 / 2017 \\
\text { Accepted on: } 18 / 01 / 2018 \\
\text { Available online: } 30 / 03 / 2018\end{array}$ & $\begin{array}{l}\text { A bacterial strain isolated from a soil sample collected from Tamil Nadu Agriculture University, Coimbatore (India) } \\
\text { was characterized as Bacillus velezensis KLP2016 by } 16 \mathrm{~S} \text { rRNA molecular typing (Accession number KY214239). } \\
\text { The extracellular lipopeptide was extracted from the cell-free fermentation medium of B. velezensis by acid- } \\
\text { precipitation method. Optimized culture conditions enhanced the lipopeptide yield ( } 2506 \mathrm{mg} / \mathrm{L} \text { ) from an earlier value } \\
\text { of } 1852 \mathrm{mg} / \mathrm{L} \text { in the fermentation broth of } B \text {. velezensis KLP2016. The crude lipopeptide of } \text { B. velezensis showed }\end{array}$ \\
\hline $\begin{array}{l}\text { Key words: } \\
\text { Anticancer activity, } \\
\text { Antifungal activity, Bacillus } \\
\text { velezensis, Lipopeptide. }\end{array}$ & $\begin{array}{l}45.0 \pm 1.2 \% \text { and } 70.6 \pm 2.4 \% \text { growth inhibition of Aspergillus niger and Mucor sp., respectively by the Agar well- } \\
\text { diffusion assay on Potato Dextrose Agar (PDA) plates. The lipopeptide nature of the acid-precipitated fraction of } B \text {. } \\
\text { velezensis was confirmed by the TLC and FTIR studies. The lipopeptide of } B \text {. velezensis exhibited strong ( } \sim 90 \%) \\
\text { cytotoxic activity against Hep2-C human cervical carcinoma cells by MTT assay. The } B \text {. velezensis strain KLP2016 } \\
\text { appeared to be a novel bacterium capable of producing potent antifungal and anticancer extracellular lipopeptide(s) } \\
\text { in the fermentation broth. }\end{array}$ \\
\hline
\end{tabular}

\section{INTRODUCTION}

The indiscriminate and excessive use of xenobiotics to control the plant diseases has disturbed the ecological balance of the soil leading to the development of resistant strains of pathogens, groundwater contamination and health risks to humans (Meena et al., 2014). Today one of the major challenges being faced by the biologists is the development of environmental friendly alternatives to the use of chemical pesticides to counter a variety of crop diseases (Ongena and Jacques, 2007; Meena and Kanwar, 2015). The increasing drug resistance in microorganisms has prompted a need to search potent alternative antimicrobial molecules like lipopeptides (LPs) with a new mode of action for use in agriculture, preservation of food and dairy products (Mandal et al., 2013). The LPs are formed by cyclic or short linear peptide linked to a lipid tail or other lipophilic molecule. The demand of LPs is surging by leaps and bound due to their utility in agriculture practices and human welfare (Meena et al., 2016). Polymyxin

"Corresponding Author

Shamsher S. Kanwar; Department of Biotechnology, Himachal Pradesh University, Shimla-171005,India.E-mail:kanwarss2000@yahoo.com
A (a type of LP) was discovered in year 1949 from a soil bacterium Bacillus polymyxa (Jones, 1949). Daptomycin was the first cyclic LP antibiotic which was approved in USA by Food and Drug Administration (FDA) for the treatment of blood and skin infections caused by some selected Grampositive microorganisms (Nakhate et al., 2013). Bacillus genus members are considered as dedicated microbial factories for the large scale production of such type of bioactive molecules (Roongswang et al., 2011; Wang et al., 2015; Dhiman et al., 2016). The LPs containing higher carbon atoms, such as $\geq 14$ in lipid tail exhibit higher antifungal activity in addition to antibacterial activity (Mandal et al., 2013). Actinobacteria species of the genus Streptomyces are reported rarely to produce antimicrobial lipopeptide(s) molecules with their applications in pharmaceutical industries (Sharma et al., 2014). The 'Polymyxin' LP binds to lipopolysaccharides of microbial cell membrane by electrostatic interaction through its $N$-terminal fatty acyl tail (Deris et al., 2014). The wide applications of the Surfactin make it a potent candidate drug to address a number of global issues in medicine (Banat et al., 2014; Singla et al., 2014), industry (Nitschke and Costa, 2007; Abdel-Mawgoud, 2008) and in environmental protection (Mulligan, 2009; Pereira et al., 2013; Gudina et al., 2015). In the present study, we attempted the production of higher 
titre of lipopeptide in the fermentation broth of $B$. velezensis KLP2016. The cytotoxicity of the bacterial lipopeptide was also checked on the human cancer cell line.

\section{MATERIALS AND METHODS}

\section{Collection of soil sample}

A soil sample was collected from tea plantation soil from the campus of Tamil Nadu Agricultural University (TNAU), Coimbatore (India) in sterile Oak-ridge tubes.

\section{Isolation of extracellular LPs producing bacterial strain}

One gram of soil was serially diluted $10^{-1}$ to $10^{-10}$ times in autoclaved Nutrient broth, $\mathrm{pH}$ 7.2. Thirty microliters of each of the dilutions was spread over Nutrient agar ( $\mathrm{pH}$ 7.2) plates. Seven discrete bacterial colonies (LP-1, LP-2, LP-3, LP-4, LP-5, LP-6 and LP-7) from Nutrient agar plate were screened for antifungal activity and one of the bacterial isolates (LP-3) exhibiting highest zone of growth inhibition against fungal growth of Aspergillus niger and Mucor sp was selected to conduct further experiments. For production and extraction of LP, the selected bacterial culture was grown at $30^{\circ} \mathrm{C}$ for $72 \mathrm{~h}$ in Erlenmeyer flasks ( $250 \mathrm{~mL}$ capacity) containing $100 \mathrm{~mL}$ of Luria Bertani (LB) broth (pH 7.0) at 200 $\mathrm{rpm}$ in a shaking incubator. The bacterial cells were removed from the fermented LB broth by centrifugation $(10,000 \mathrm{~g}$ for $10 \mathrm{~min}$ at $4^{\circ} \mathrm{C}$ ). The cell-free broth was collected and its $\mathrm{pH}$ was adjusted to 2.0 by adding $6 \mathrm{~N} \mathrm{HCl}$. The acid precipitate recovered by centrifugation $\left(12,000 \mathrm{~g}\right.$ for $15 \mathrm{~min}$ at $\left.4^{\circ} \mathrm{C}\right)$ was extracted with methanol (Gover et al., 2010). The methanol (1 mL) extracted LP-fraction was bio-assayed for antifungal activity against both Mucor sp. and A. niger.

\section{Antifungal activity assay of isolated lipopeptide(s)}

The lipopeptide extract $(50 \mu \mathrm{L})$ was bio-assayed on Potato Dextrose Agar (PDA) medium against A. niger and Mucor sp. by Agar well-diffusion method (Tagg and McGiven, 1971). The test fungus culture was transferred in the middle of the PDA plate and at the periphery, an appropriate amount of methanol extracted lipopeptide preparation was loaded aseptically in the well (diameter $6 \mathrm{~mm}$ ). The Petri plates were incubated at $30^{\circ} \mathrm{C}$ and the zones of inhibition (\%) against each of the fungal pathogens were recorded after 3 days using the following equation;

$$
\frac{\mathrm{Dt}-\mathrm{Dc}}{\mathrm{Dc}} \times 100
$$

Where Dc: Average diameter of control mycelial colony; Dt: Average diameter of mycelial colony treated with LP.

\section{Differential staining and 16S rRNA sequencing of the selected bacterial isolate LP-3}

Gram's staining and endospore staining of the selected bacterial isolate was performed by using commercial kits (Hi Media, Mumbai, India). The selected bacterial isolate 'LP-3' was also characterized by $16 \mathrm{~S}$ rRNA analysis. The gene sequences of related bacterial strains were obtained from the server through the BLAST with the help of forward and reverse sequence for alignment using CLUSTAL-W program of MEGA software version 6.0 (Tamura et al., 2007). An evolutionary dendrogram was deduced by using the Neighbour-Joining method. The Bootstrap consensus tree generated from 500 replicates was taken to present the dendrogram and evolutionary history of the analysed taxa (Felsenstein, 1985).

\section{Optimization of nitrogen and carbon source for production of} lipopeptide by the B. velezensis KLP2016

The effect of a few nitrogen sources on the production of lipopeptide by B. velezensis was studied by adding $1 \%(\mathrm{w} / \mathrm{v})$ of chosen (ammonium sulphate, peptone, sodium nitrate, ammonium nitrate, beef extract, ammonium chloride or yeast extract) nitrogen source to the production broth ( $\mathrm{pH}$ 7.0). Similarly, the effect of the selected carbon source(s) on the production of LP by the bacterial isolate was studied by adding $1 \%(\mathrm{w} / \mathrm{v})$ of chosen (glucose, sucrose, fructose, maltose, sorbitol and starch) carbon source to the LB broth supplemented with $1 \%$ beef extract ( $\mathrm{pH} 7.0)$. The inoculated broths $(4 \% \mathrm{v} / \mathrm{v}$ of $10 \mathrm{~h}$ seed culture) were incubated for $48 \mathrm{~h}$ at $30^{\circ} \mathrm{C}$ under shaking at $200 \mathrm{rpm}$. Results were recorded as yield of the LP in fermentation broth.

\section{Optimization of production time, temperature and $\mathrm{pH}$}

The effect of incubation time (24, 48, 72 and $96 \mathrm{~h}$ ) was tested to improve the production of LP by the bacterial isolate. The inoculated broths ( $\mathrm{pH} 7.0 ; 4 \% \mathrm{v} / \mathrm{v}$ of $10 \mathrm{~h}$ old seed culture) were kept at $30^{\circ} \mathrm{C}$ for $24,48,72$ and $96 \mathrm{~h}$ under shaking (200 $\mathrm{rpm})$. The effect of incubation temperature $(25,30,35,37,40$ and $45^{\circ} \mathrm{C}$ ) was tested on the LP production by $B$. velenzensis under continuous shaking. To study the effect of $\mathrm{pH}(4,5,6$, 7, 8 and 9) of LB broth, the broths were individually set to the selected $\mathrm{pH}$ value followed by inoculation as mentioned above. The crude lipopeptide was extracted and analysed for yield of LP at above parameters.

\section{SDS-PAGE of the crude lipopeptide preparation}

The crude lipopeptide preparation was analysed to determine its molecular weight by denaturing SDS-PAGE $(16 \%)$ in comparison to Iturin and Surfactin used as reference lipopeptide molecules. Silver stain was used to visualize the protein bands on SDS-PAGE.

\section{Thin layer chromatography (TLC) analysis of LP}

A mobile phase consisting of chloroform: methanol: water $(65: 25: 4)$ was prepared. The 0.22 micron membrane sterilized LP was applied ( $5 \mu \mathrm{L})$ on to the TLC plate. After sample loading, the TLC plate (SDFCL, Silica gel $60 / \mathrm{UV}_{254}, 0.5 \mathrm{~cm} \times 20$ $\mathrm{cm}$ and thickness: $0.2 \mathrm{~mm}$ ) was transferred into the solvent/mobile phase. The developed TLC plate was removed and allowed to air dry. The TLC plate was sprayed uniformly with ninhydrin solution $\left(0.25 \%\right.$ in ethanol) and placed in an oven at $110^{\circ} \mathrm{C}$ for $20 \mathrm{~min}$ to visualize the LP spots. To test the presence of the lipid moiety, the TLC plate was sprayed with water. $R_{\mathrm{f}}$ value of the extracted LP was calculated by the following formula (Razafindralambo et al., 1993);

$$
\mathrm{Rf}=\frac{\text { Distance travelled by the solute from origin }(\mathrm{cm})}{\text { Distance travelled by the solvent from origin }(\mathrm{cm})}
$$




\section{Partial characterization of LPs by the spectrophotometry (FTIR)}

The chemical nature of the acid precipitated and methanol extracted LP of B. velezensis KLP2016 was confirmed by FTIR analysis (Perkin Elmer; SAIF, Panjab University, Chandigarh). FTIR spectra of lipopeptide were observed at 400-4000 wave numbers $\left(\mathrm{cm}^{-1}\right)$. Structure-property relationship of the isolated lipopeptide was partially determined by the FTIR spectra to confirm the insertion reactions and fictionalization.

\section{Effect of the LP on a human Hep2C cervical cancer cell line by the MTT assay}

The viability of human cervical carcinoma Hep2C cells was detected using the MTT dye which forms formazan crystals of the blue colour by a reduction process by the mitochondrial dehydrogenase present in living mammalian cells. The Hep2-C cells suspended at a final concentration of $1.2 \times 10^{4}$ cells $/ \mathrm{mL}$ in the Dulbecco's Modified Eagle's Medium (DMEM) containing $5 \%$ Foetal bovine serum were seeded in 96-well plates. Plates were kept for growth of $\mathrm{Hep} 2 \mathrm{C}$ cells for $24 \mathrm{~h}$ in a $\mathrm{CO}_{2}$ incubator $\left(37^{\circ} \mathrm{C} ; 4 \% \mathrm{CO}_{2}\right)$. Thereafter, the cells were treated with the 0.22 micron membrane sterile LP sample at varying concentrations (5, $15,25,35,45,55,65$ and $75 \mu \mathrm{g} / \mathrm{mL})$. After $24 \mathrm{~h}$ of LP treatment, MTT ( $5 \mathrm{mg} / \mathrm{mL}$ in distilled water) was added to each of the wells of 96-well plate followed by gently mixing and incubation for 1 $\mathrm{h}$ in dark (Wang et al., 2007; Sharma et al., 2017). The DMEM was completely decanted and intracellular formazan crystals were dissolved in DMSO $(100 \mu \mathrm{L})$. The absorbance of each well was measured at $570 \mathrm{~nm}$ with an automated plate reader (MULTISCAN EX, Thermo Electron Corporation, China). The LP-treated cells were compared with the placebo (cells treated with phosphate buffered saline $\mathrm{pH}$ 7.2) saline.
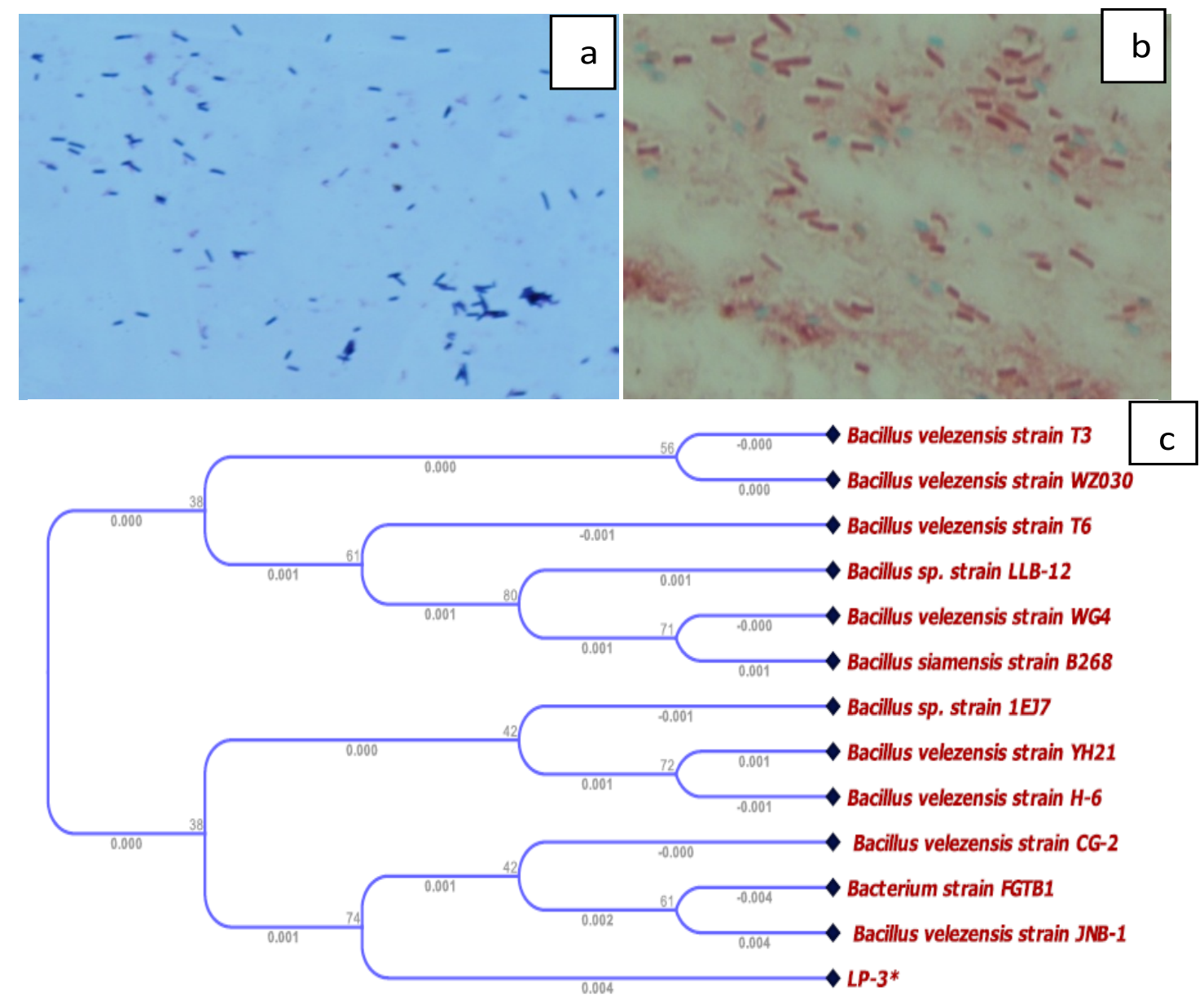

Fig. 1: Bacterial isolate LP-3. (a) Gram's staining image showed rod shaped bacteria; (b) Green colour rod shaped endospore and (c) Phylogenetic tree of B. velezensis KLP2016 (mentioned as isolate LP-3) generated by software MEGA 6.0 version showed prominent similarity of the investigated amplified DNA (for r-RNA) to 12 nearest neighbours.

\section{RESULTS}

Isolation and characterization of extracellular LP-producing bacterial isolate

The LPs producing bacterial colonies were isolated from the soil sample. The isolation was done in a Nutrient broth at $\mathrm{pH}$ 7.2. Seven bacterial colonies were isolated, maintained as pure culture on Nutrient agar plates and screened individually for their antifungal activities against $A$. niger and Mucor sp. One of the isolates (LP-3; Figure 1a), which was Gram positive, rod shaped 
bacterium possessed highest antifungal activity was selected for extraction of LPs. The old culture of this bacterium on staining (with malachite green and counterstaining with safranin) also showed presence of green coloured endospores among vegetative cells (Figure 1b).

\section{Identification of bacterial isolate by $16 \mathrm{~S}$ r-RNA sequencing}

The bacterial isolate 'LP-3' was characterized by $16 \mathrm{~S}$ r-RNA analysis. The gene sequences of closely related bacterial strains were retrieved from a server through the BLAST with the help of forward and reverse sequence using CLUSTAL-W program of MEGA software version 6.0. The Bootstrap consensus tree generated from 500 replicates was taken to present the dendrogram and evolutionary history of the analysed taxa (Figure 1c). The bacterial isolate 'LP-3' was identified as B. velenzensis strain KLP2016 (Accession number KY214239).

\section{Antifungal activity of extracellular lipopeptide fraction of $B$. velezensis}

Antifungal activity of the extracted LP of $B$. velezensis was tested against the growth of $A$. niger and Mucor sp on PDA Petri plates. The extracted LP preparation of $B$. velezensis showed the highest antifungal activity of $70.6 \pm 2.4 \%$ against Mucor $\mathrm{sp}$. (Figure 2)

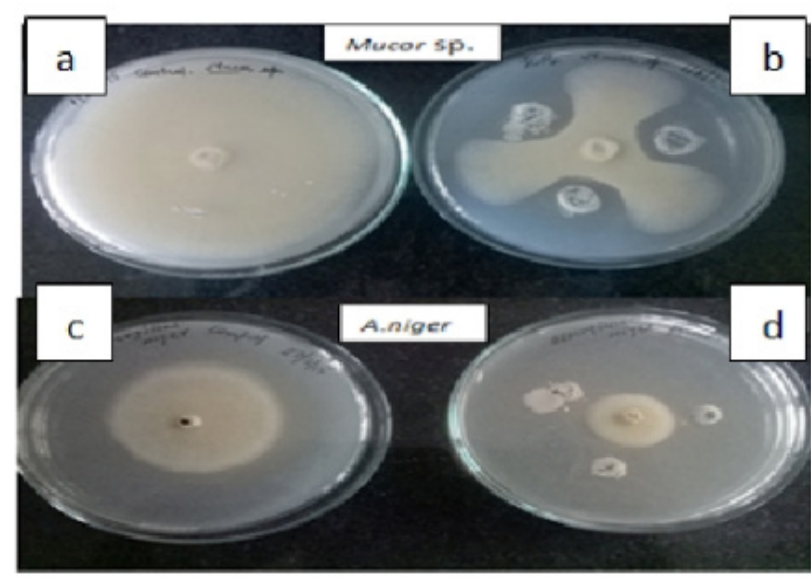

Fig. 2: Antifungal properties of the crude lipopeptide(s) preparation extracted from the B. velezensis against Mucor sp. (b): 70.6 $\pm 2.4 \%$ ) and Aspergillus niger (d): $45.0 \pm 1.2 \%$ ), respectively. Separate placebo controls were kept for monitoring Mucor sp. (a) and Aspergillus niger (c) growth-inhibition assay.

\section{Optimization of nitrogen and carbon source for production of} LPs by $B$. velezensis

The effects of various selected nitrogen and carbon sources on the production of extracellular LP by $B$. velezensis KLP2016 were studied. The recorded results indicated that beefextract was the best nitrogen source for the optimal yield of lipopeptides (1852 mg/L; Figure 3a) by B. velezensis KLP2016. Among various carbon sources (sucrose, fructose, sorbitol, glucose, starch and maltose), the sorbitol was the most preferred carbon source for LP production by B. velezensis KLP2016 (1900 $\mathrm{mg} / \mathrm{L}$; Figure 3b).

Optimization of incubation time, temperature and $\mathrm{pH}$ for the LPs production by the $B$. velezensis

The recorded results showed that a maximum yield of LPS (2075 mg/L; Figure 3c) in the fermentation broth by B. velezensis KLP2016 was observed after $72 \mathrm{~h}$. Thus the LP preparation extracted after $72 \mathrm{~h}$ was considered most suitable to harvest antifungal LPs from B. velezensis KLP2016. LPs production was also analysed at different growth temperatures and the maximum lipopeptide yield $(2135 \mathrm{mg} / \mathrm{L}$; Figure $3 \mathrm{~d})$ was observed at $30^{\circ} \mathrm{C}$. Study of the effect of the different $\mathrm{pH}(4,5,6,7,8$ and 9) of the production broth [Luria Bertani broth containing $1 \%$ beef extract and $1 \%$ sorbitol] on LPs production by B. velezensis KLP2016 showed that a $\mathrm{pH} 7$ of the broth supported the maximum LP (2506 $\mathrm{mg} / \mathrm{L}$; Figure $3 \mathrm{e}$ ) production under shake flask culture.

\section{SDS-PAGE and TLC analysis of the crude lipopeptide of $\boldsymbol{B}$. velezensis strain}

The analysis of crude lipopeptide preparation of $B$. velezensis KLP2016 under denaturing SDS-PAGE (16\%; Figure 4a) in comparison to reference Iturin and Surfactin revealed that the extracted bacterial lipopeptide possessed a protein band at the same position as that of the Iturin and Surfactin reference compounds $(\sim 1.1 \mathrm{kDa})$. On the basis of obtained results, the extracted LP preparation appeared to be Iturin- or Surfactin-type of lipopeptide.

The TLC plate containing lipopeptide fraction was sprayed with ninhydrin for the detection of peptide/amino acid residues, and water for the presence of a lipid moiety in the LP (Figure $4 \mathrm{~b} \& \mathrm{c}$ ). The $\mathrm{R}_{\mathrm{f}}$ values were recorded as 0.53 and 0.79 when TLC plate was sprayed with the ninhydrin for protein detection, while $\mathrm{R}_{\mathrm{f}}$ of 0.62 was observed when TLC plate was sprayed with water for presence of lipid moiety.

\section{FTIR spectrum of the isolated lipopeptide preparation}

The chemical nature of the isolated LP fraction was confirmed by FTIR spectra (Figure 5). The IR spectrum showed a peak at $3284.32 \mathrm{~cm}^{-1}$ which was due to the $\mathrm{N}-\mathrm{H}$ stretching vibrations, a typical characteristic of carbon containing compound with amine group. The peak recorded at $3052.32 \mathrm{~cm}^{-1}$ was due to a long aliphatic chain that showed the presence of a long carbon chain. A peak observed at $2958.30 \mathrm{~cm}^{-1}$ signified the presence of a long stretch of $\mathrm{C}-\mathrm{CH}_{3}$ bond or long alkyl chains. Other significant peaks at $2871.62 \mathrm{~cm}^{-1}$ in the spectra corresponded to $\mathrm{C}-\mathrm{H}$ in long alkyl chain. The peaks observed at $1658.30 \mathrm{~cm}^{-1}$ revealed the presence of CO-N stretching in the peptide bond in the lipopeptide molecule. Peaks at $1408.42 \mathrm{~cm}^{-1}$ were due to the aromatic group in the lipopeptide preparation. Peak at $1233.45 \mathrm{~cm}^{-1}$ showed the $\mathrm{C}-\mathrm{O}$ deformation vibration. This FTIR spectrum of the extracted LP of $B$. velezensis KLP2016 thus confirmed the lipopeptide nature of the acid-precipitated fraction of cell-free fermentation broth. 

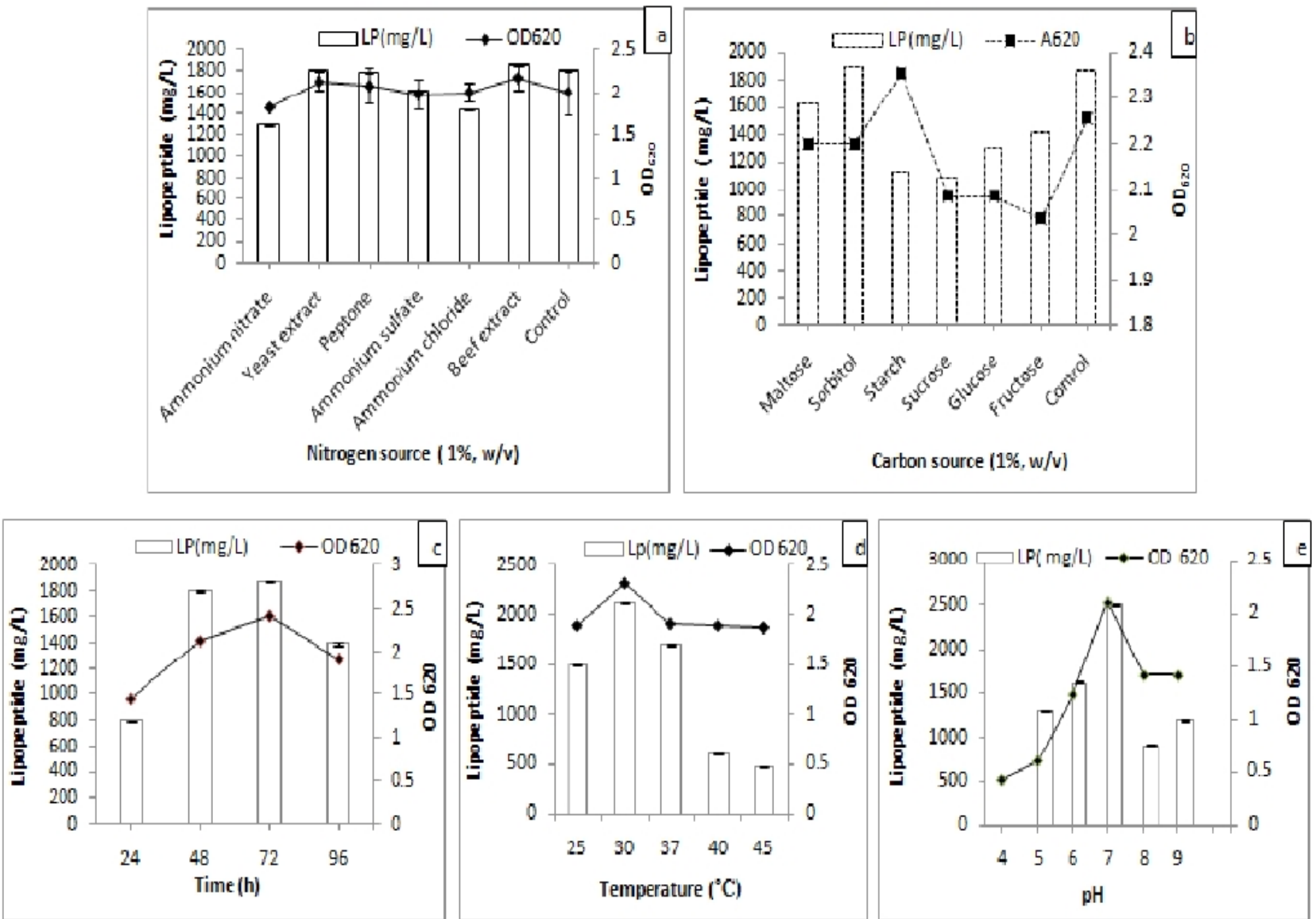

Fig. 3: Optimization of different nitrogen and carbon source for LPs production by the B. velezensis. (a) Nitrogen source optimization; (b) Carbon source optimization; (c) Optimization of the incubation time; (d) Optimization of the temperature and (e) Optimization of $\mathrm{pH}$ of fermentation broth.

L1 L L2 L3

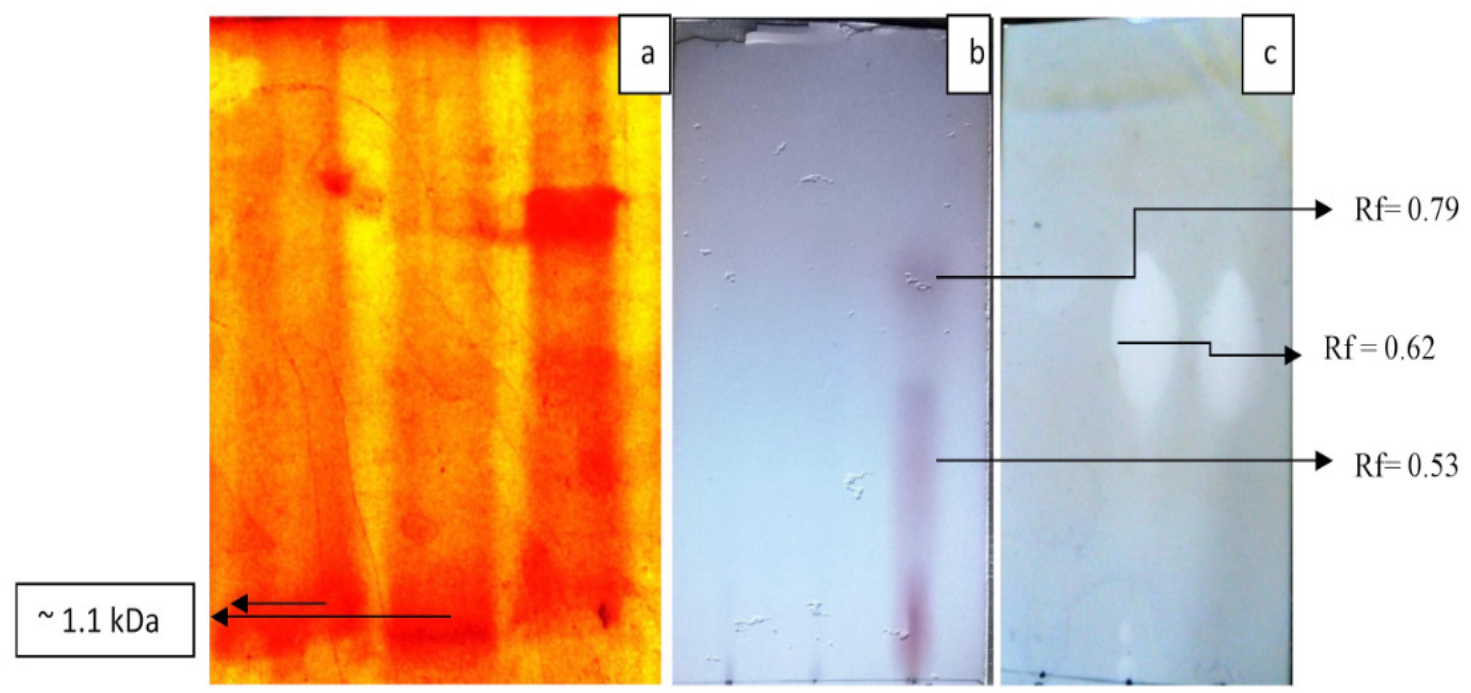

Fig. 4: SDS-PAGE and TLC of the crude lipopeptide preparation with reference to authentic Surfactin and Iturin. (a) L1: Band of authentic Surfactin, L2: Band of authentic Iturin A and L3: Bands of crude lipopeptide preparation. (b) TLC plate sprayed with ninhydrin produced blue violet spots indicating presence of the peptide moiety and (c) TLC plate sprayed with water showed white spots indicating the presence of lipid moiety in the acid-precipitated fraction of $B$. velezensis KLP2016 cell-free broth. 
RC SAIF PU, Chandigarh

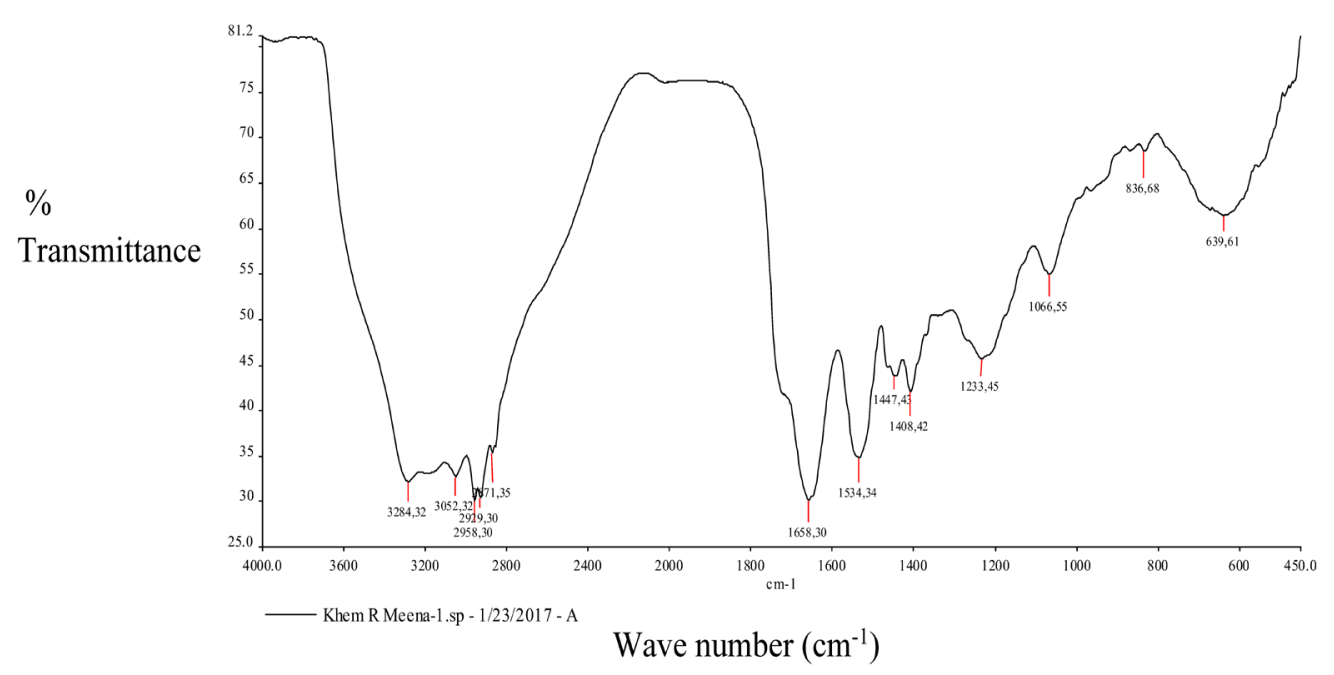

Fig. 5: FTIR spectra of the LP extracted from the fermentation broth of B. velezensis KLP2016.

\section{MTT assay}

To establish the concentration of LP fraction necessary to inhibit the growth/proliferation of Hep2-C cells, these cells plated in 96-well plates were treated with LP fraction at concentration varying from 5 to $75 \mu \mathrm{g} / \mathrm{mL}$ (Table 1). The maximum growth inhibition $(94.24 \pm 2.3 \%)$ of human cervical Hep2-C cancer cells was observed at $75 \mu \mathrm{g} / \mathrm{mL}$ concentration of LP of B. velezensis KLP2016.

Table 1: Killing of Hep2-C cells by lipopeptide of Bacillus velezensis KLP2016.

\begin{tabular}{cc}
\hline Lipopeptide $(\boldsymbol{\mu g} / \mathbf{m L})$ & Hep2C cell death $(\%)$ \\
\hline 5 & $45.84 \pm 3.24$ \\
15 & $51.07 \pm 2.45$ \\
25 & $84.23 \pm 2.13$ \\
35 & $91.01 \pm 1.52$ \\
45 & $88.01 \pm 2.42$ \\
55 & $84.82 \pm 3.17$ \\
65 & $86.37 \pm 2.41$ \\
75 & $91.24 \pm 3.43$ \\
\hline
\end{tabular}

\section{DISCUSSION}

The LPs are considered as the versatile bio-weapons due to their antibacterial, antifungal, anticancer or antitumor applications. A bacterial strain isolated from the oil contaminated desert site in Gujarat (India) has been previously reported for the lipopeptide production to establish its biosurfactant application in microbial-enhanced oil recovery (Sujata et al., 2016). The coastal sea-sediment samples from three different contaminated locations of Nagapattinam fishing harbor, Tamil Nadu, India have been reported for isolation of lipopeptide-producing microbes (Panagal et al., 2016). In our study, a bacterium KLP2016 was isolated from the soil collected from the TNAU, Coimbatore. The bacterial isolate characterized by the $16 \mathrm{~S}$ rRNA sequencing was found to be a Bacillus velezensis strain which has not been reported earlier for the LP production.

The selection of suitable carbon and nitrogen source are among most important growth nutrients/factors which might affect the lipopeptide production by bacterial cells. The basal salt medium containing urea has been reported to produce $720 \mathrm{mg} / \mathrm{L}$ LPs from B. subtilis SPB1 strain after the $48 \mathrm{~h}$ of incubation. The production of these LPs was enhanced to $750 \mathrm{mg} / \mathrm{L}$ when the concentration of urea was kept $5.0 \mathrm{~g} / \mathrm{L}$, and the medium contained glucose $(40 \mathrm{~g} / \mathrm{L})$ as a carbon source (Abushady et al., 2005). A medium containing $20.0 \mathrm{~g} / \mathrm{L}$ carbon source, $2.0 \mathrm{~g} / \mathrm{L}$ nitrogen source, $3.0 \mathrm{~g} / \mathrm{L} \mathrm{K}_{2} \mathrm{HPO}_{4} .3 \mathrm{H}_{2} \mathrm{O}, 10 \mathrm{~g} / \mathrm{L} \mathrm{NaH}_{2} \mathrm{PO}_{4} .2 \mathrm{H}_{2} \mathrm{O}, 0.2 \mathrm{~g} / \mathrm{L}$ $\mathrm{MgSO}_{4} \cdot \mathrm{H}_{2} \mathrm{O}, 0.002 \mathrm{~g} / \mathrm{L} \mathrm{MnCl} \cdot 4 \mathrm{H}_{2} \mathrm{O}$ and $0.2 \mathrm{~g} / \mathrm{L}$ yeast extract enhanced the Surfactin production (Liu et al., 2012). Sucrose (a carbon source) enabled the Bacillus sp. to reach a maximum yield of $102.0 \mathrm{mg} / \mathrm{L} \mathrm{C15-Surfactin}$ while ammonium nitrate (a nitrogen source) also enhanced the yield of Surfactin $(99.6 \mathrm{mg} / \mathrm{L})$. A $B$. subtilis produced 720 to $2040 \mathrm{mg} / \mathrm{L}$ of biosurfactant at the end of the fermentation (Dhouha and Semia, 2011). However, in our study, among various nitrogen sources (ammonium nitrate, yeast extract, peptone, beef extract, ammonium chloride etc.), beef extract ( $1 \%$; $\mathrm{w} / \mathrm{v}$ ) was the best nitrogen source for extracellular production of LPs (1812 to $1852 \mathrm{mg} / \mathrm{L})$. The least positive effect was observed in case of use of ammonium nitrate in the broth $(1292 \mathrm{mg} / \mathrm{L})$ in comparison to use beef extract. When concentration of beef extract was optimized $(1 \%$; w/v), the lipopeptide yield reached $1864 \mathrm{mg} / \mathrm{L}$. In the present study, among various carbon sources (maltose, sorbitol, starch, sucrose, glucose and fructose), recorded results indicated that sorbitol $(1 \%)$ was best carbohydrate to produce extracellular LPs by B. velezensis KLP2016 (1900 mg/L; Figure 3b). 
The bioprocess/fermentation temperature also influences the composition of LPs produced by B. subtilis RB14, with Iturin A predominantly being synthesized at $25^{\circ} \mathrm{C}$ while Surfactin production was favoured at $37^{\circ} \mathrm{C}$ (Ohno et al., 1995). About 1900 $\mathrm{mg} / \mathrm{L}$ of LPs were produced at temperature $40^{\circ} \mathrm{C}$ by $B$. subtilis. Another B. subtilis $\mathrm{K} 1$ strain exhibited maximum growth at the $\mathrm{pH}$ range of 7.0 to 9.0 with maximum production of antifungal activity at pH 9.0 (Mizumoto and Shoda, 2007). In our study, the results showed that a maximum yield of LPs by $B$. velezensis KLP2016 was observed after $72 \mathrm{~h}$ ( $2075 \mathrm{mg} / \mathrm{L}$; Figure 5A). Thus the lipopeptides acid-precipitated in cell-free broth of $B$. velezensis KLP2016 after $72 \mathrm{~h}$ of fermentation was considered most productive to extract LPs for potent antifungal activity. Lipopeptide(s) production was also analyzed at different fermentation temperatures $(25,30,35$, 37,40 and $\left.45^{\circ} \mathrm{C}\right)$, and interestingly the maximum LPs yield $(2135$ $\mathrm{mg} / \mathrm{L}$; Figure $3 \mathrm{~d}$ ) was observed at $30^{\circ} \mathrm{C}$. At the temperature above of $37^{\circ} \mathrm{C}\left(40^{\circ} \mathrm{C}\right.$ and $\left.45^{\circ} \mathrm{C}\right)$, the $B$. velezensis KLP2016 didn't show much growth as well as lipopeptide yield. The study of the effect of the $\mathrm{pH}(4,5,6,7,8$ and 9$)$ of the optimized fermentation broth showed that a $\mathrm{pH} 7$ was the best for lipopeptide $(2506 \mathrm{mg} / \mathrm{L}$; Figure 3e) production $B$. velezensis KLP2016. After optimization of all the bioprocess/fermentation conditions, the LPs yield in the production broth enhanced from an initial value of $1852 \mathrm{mg} / \mathrm{L}$ to a maximum of $2506 \mathrm{mg} / \mathrm{L}$, which thus indicated approximately $35 \%$ higher yield of LPs over the initial unoptimized broth and fermentation conditions.

In a recent report, a Bacillus sp. CCMI 1051 exhibited antifungal activity $25.7 \pm 1.00,23.1 \pm 0.93$ and $22.1 \pm 0.19$ mm against Mucor sp., Alternaria sp. and Cladosporium sp., respectively (Silva et al., 2016). In our study, lipopeptide fraction of $B$. velezensis KLP2016 inhibited the growth of $A$. niger and Mucor sp. on PDA by $45.0 \pm 1.2$ and $70.6 \pm 2.4 \%$, respectively. The lipopeptide fraction of $B$. velezensis KLP2016 was also checked for the anticancer activity against the human Hep2-C cell line (A derivative of HeLa cells). The outcome was startling as $91.2 \%$ cells death was observed at a concentration of $75 \mu \mathrm{g} /$ $\mathrm{mL}$ of LPs of $B$. velezensis KLP2016. The SDS-PAGE of the LP fraction of $B$. velezensis KLP2016 showed presence of a protein of $\sim 1.1 \mathrm{kDa}$ which was similar to the molecular size of Surfactin and Iturin reference molecules. Presence of both the lipid and protein moiety in the lipopeptide of B. velezensis KLP2016 was confirmed by the TLC. The FTIR spectra of the crude lipopeptide also confirmed the lipopeptide nature of the acid-precipitated cellfree fermentation broth of B. Velezensis KLP2016.

\section{CONCLUSION}

The selected bacterium B. velezensis KLP2016 (Accession number KY214239) was found to produce extracellular LP having potent antifungal and anticancer activities. The lipopeptide preparation however, showed strongest antifungal ( $70.6 \pm 2.4 \%$ growth inhibition) activity against Mucor sp. Optimization of the bioprocess conditions resulted in an enhanced lipopeptide yield $(2506 \mathrm{mg} / \mathrm{L})$ in the fermentation broth of B. velezensis KLP2016 from an earlier value of $1852 \mathrm{mg} / \mathrm{L}$. The MTT assay was performed on human Hep2C cells to check the cytotoxicity of the lipopeptide fraction. The extracted LP preparation appeared to contain Iturin and Surfactin on the basis of FTIR and SDS PAGE analysis. This is a novel bacterium, which has not been reported in the literature earlier for the production of lipopeptides.

\section{ACKNOWLEDGEMENTS}

This work has been funded by Department of Biotechnology, Ministry of Science and Technology, New Delhi under a DBT-JRF Fellowship grant awarded to one of the authors (KRM) vide a Letter No. DBT-JRF/2011-12/270. The authors are thankful to Department of Biotechnology and Sub-DIC Facility, Ministry of Science and Technology, New Delhi and Department of Biotechnology, Himachal Pradesh University, Shimla for the instrumental facilities and computational support for this work.

\section{CONFLICT OF INTEREST}

There is no conflict of interest among the authors or with their parent institution.

\section{REFERENCES}

Abdel-Mawgoud AM, Aboulwafa MM, Hassouna NAH. Characterization of surfactin produced by Bacillus subtilis isolates BS5. Appl Biochem Biotechnol, 2008; 150: 289-303.

Abushady HM, Bashandy AS, Aziz NH, Ibrahim HMM Molecular characterization of Bacillus subtilis surfactin producing strain and the factors affecting its production. Int J Agric Biol, 2005; 7: 337-344.

Banat IM, Franzetti A, Gandolfi I. Microbial biosurfactants production, applications and future potential. Appl Microbiol Biotechnol, 2010; 87: 427-444.

Deris ZZ, Swarbrick JD, Roberts KD, Azad MAK, Akter J, Horne AS, Nation RL, Rogers KL, Thompson PE, Velkov T, Li J. Probing the penetration of anti-microbial Polymyxin lipopeptides into Gramnegative bacteria. Bioconjugate Chem, 2014; 25: 750-760.

Dhiman R, Meena KR, Sharma A, Kanwar SS. Biosurfactants and their screening methods. Res J Recent Sci, 2016; 5: 1-6.

Dhouha G and Semia EC. Enhancement of Bacillus subtilis lipopeptide biosurfactants production through optimization of medium composition and adequate control of aeration. Biotechnol Res Int, 2011, 2011:1-6.

Felsenstein J. Confidence limits on phylogenies: An approach using the bootstrap. Evol, 1985; 39: 783-791.

Gover M, Nain L, Singh SB, Saxena AK. Molecular and biochemical approaches for characterization of antifungal trait of potent bio-control agent Bacillus subtilis RP24. Curr Microbiol, 2010; 60: 99-106.

Gudina EJ, Rodrigues AI, Alves E, Domingues MR, Teixeira JA, Rodrigues LR. Bioconversion of agro-industrial by-products in rhamnolipids toward applications in enhanced oil recovery and bioremediation. Bioresour Technol, 2015; 177: 87-93.

Jones TS. Chemical evidence for the multiplicity of the antibiotics produced by Bacillus polymyxa. Ann N Y Acad Sci, 1949; 51 909-916.

Liu X, Ren B, Gao H, Liu M, Dai H, Song F, Yu Z, Wang S, $\mathrm{Hu}$ J, Kokare CR, Zhang L. Optimization for the production of surfactin with a new synergistic antifungal activity. PLoS ONE, 2012; 7: e34430. doi:10.1371/journal.pone.0034430.

Mandal SM, Sharma S, Pinnaka AK, Kumari A, Korpole $\mathrm{S}$. Isolation and characterization of diverse anti-microbial lipopeptides produced by Citrobacter and Enterobacter. BMC Microbiol, 2013; 13: 1-9.

Meena KR and Kanwar SS. Lipopeptides as the antifungal and antibacterial agents: applications in food safety and therapeutics. BioMed Res Int, 2015; 2015: 1-9.

Meena KR, Dhiman R, Sharma A, Kanwar SS. Applications of lipopeptide(s) from a Bacillus sp: An overview. Res j Recent Sci, 2016; 5: 50-54. 
Meena KR, Saha D, Kumar R. Isolation and partial characterization of iturin like lipopeptides (a bio-control agent) from a Bacillus subtilis strain. Int J Curr Microbiol Appl Sci, 2014; 3: 121-126.

Mizumoto S and Shoda M. Medium optimization of antifugal lipopeptide, Iturin A, production by Bacillus subtilis in solid state fermentation by response surface methodology. Appl Microbiol Biotechnol, 2007; 76: 101-108.

Mulligan CN. Recent advances in the environmental applications of biosurfactants. Curr Opin Colloids Int Sci, 2009; 14: 372 -378.

Nakhate $\mathrm{PH}$, Yadav VK, Pathak AN. A review on daptomycin: the first US-FDA approved lipopeptide anti-biotics. J Scientific Innov Res, 2013; 2: 970-980.

Nitschke $M$ and Costa SGVA. Biosurfactants in food industry. Trends Food Sci Technol, 2007; 18: 252 -259.

Ohno A, Ano T, Shoda M. Effect of temperature on production of lipopeptides antibiotics, Iturin A and Surfactin by dual producer, B. subtlis RB14, in solid state fermentation. J Ferment Bioeng, 1995; 80: 517-519.

Ongena $\mathrm{M}$ and Jacques P. Bacillus lipopeptides: versatile weapons for plant disease biocontrol. Trends Microbiol, 2007; 16: 115-125.

Panagal M, Pethanen SK, Shanmugasundaram SB. Economic production and oil recovery efficiency of a lipopeptide biosurfactant from a novel marine bacterium Bacillus simplex, Achiev Life Sci, 2016; 10: $102-110$.

Pereira JFB, Gudiña EJ, Costa R, Vitorino R, Teixeira JA, Coutinho JAP. Optimization and characterization of biosurfactant production by Bacillus subtilis isolates towards microbial enhanced oil recovery applications. Fuel, 2013; 111:259-268.

Razafindralambo H, Paquot M, Hbid C, Jacques P, Destain J, Thonart P. Purification of antifungal lipopeptides by reversed-phase high performance liquid chromatography. J Chromatogr, 1993; 639: 81-85.

Roongswang N, Washio K, Morikawa M. Diversity of nonribosomal peptide synthetases involved in the biosynthesis of lipopeptide biosurfactants. Int Mol Sci, 2011; 12:141-172.

Sharma A, Meena KR, Kanwar SS. Molecular characterization and bioinformatics studies of a lipase from Bacillus thermoamylovorans
BHK67. Int J Biol Macromol, 2017; 107: 2131-2140.

Sharma D, Mandal SM, Manhas RK. Purification and characterization of a novel lipopeptide from Streptomyces amritsarensis sp. active against methicillin-resistant Staphylococcus aureus. AMB Express, 2014; 4: 1-9.

Silva M, Pereira A, Teixeira D, Candeias A, Caldeira AT. Combined Use of NMR, LC-ESI-MS and antifungal tests for rapid detection of bioactive lipopeptides Produced by Bacillus. Adv Microbiol, 2016; 6: 788-796

Singla RK, Dubey HD, Dubey AK. Therapeutic spectrum of bacterial metabolites. J Pharma Sci, 2014; 4: 52-64.

Sujata SJ, Sanket JJ, Geetha SJ. Lipopeptide production by Bacillus subtilis R1 and its possible applications. Braz J Microbiol, 2016; 2016: 1-10

Tagg JR and McGiven AR. Assay system for bacteriocins. Appl Microbiol, 1971; 21: 943-943.

Tamura K, Dudley J, Nei M, Kumar S. MEGA4: Molecular evolutionary genetics analysis (MEGA) software version 4.0. Mol Biol Evol, 2007; 24: 1596-1599.

Wang CL, Ng TB, Yuan F, Liu ZK, Liu F. Induction of apoptosis in human leukemia K562 cells by cyclic lipopeptide from Bacillus subtilis natto T-2. Peptides, 2007; 28: 1344-1350.

Wang T, Liang Y, Wu M, Chen Z, Lin J, Yang L. Natural products from Bacillus subtilis with antimicrobial properties. Chinese J Chem Eng, 2015; 23: 744-754.

How to cite this article:

Meena KR, Tandon T, Sharma A, Kanwar SS. Lipopeptide antibiotic production by Bacillus velezensis KLP2016. J App Pharm Sci, 2018; 8(03): 091-098. 